DOI: $\underline{\text { https://doi.org/10.31933/dijemss.v2i4 }}$

Received: $22^{\text {nd }}$ March 2021, Revised: $15^{\text {th }}$ April 2021, Publish: $30^{\mathrm{h}}$ June 2021

\begin{tabular}{|c|c|c|}
\hline PUNASTISTER & $\begin{array}{l}\text { DIJEMSS } \\
\text { DINASTI INTERNATIONAL JOURNAL } \\
\text { OF EDUCATION MANAGEMENT AND } \\
\text { SOCIAL SCIENCE }\end{array}$ & $\begin{array}{r}\text { https://dinastipub.org/DIJEMSS } \\
\text { editor@dinastipub.org } \\
08117401455 \text { (1) }\end{array}$ \\
\hline
\end{tabular}

\title{
STRATEGIC MANAGEMENT OF CHANGE IN ISLAMIC EDUCATION INSTITUTIONS (A CASE STUDY AT ISLAMIC EDUCATION INSTITUTION OF SYAFANA ISLAMIC SCHOOL SERPONG)
}

\author{
Eva Iryani ${ }^{1 *}$ M. Masruri' ${ }^{2}$ Maisah Maisah $^{3}$ \\ 1) Student Postgraduate of Uin Sulthan Thaha Saifuddin Jambi, Indonesia, \\ evairyani@unja.ac.id \\ 2) Student Postgraduate of Uin Sulthan Thaha Saifuddin Jambi, Indonesia, \\ masrurimuhammad81@gmail.com \\ ${ }^{3)}$ Lecture Postgraduate of Uin Sulthan Thaha Saifuddin Jambi, Indonesia, \\ maisahmasisah123@gmail.com
}

Corresponding Author: Eva Iryani

\begin{abstract}
This paper shows the role of Syafana Islamic School's strategic management in the transformation of the implementation of the full-day program by changing it to a boarding school system. These changes are not only in the aspect of the learning system, but even on the curriculum side which uses the combination of several curricula; Diknas, Egypt (Al-Azhar) and Cambridge are integrated into the concept of Islamic boarding school, the change process is observed and analyzed using the SWOT analysis model (Strength, Weakness ,Opportunity and Threath) with an emphasis on the process of changing the system and curriculum applied by Syafana Islamic School. With the results and findings, there is a strategic management in the transformation by integrating and using four collaborative strategies. First, the Strategic Opportunity Strategy. With the model of merging and accumulating strengths by exploiting various opportunities. Second, the Strength Threath Strategy with knowledge of the strengths possessed can see and anticipate existing threats. Third, the Weakness Opportunity Strategy, the opportunity to be a major factor in efforts to overcome the weaknesses in this institution and Finally the Weakness Threath Strategy. Defense efforts are still analyzed and carried out in order to minimize weaknesses and threats from outside the institution.
\end{abstract}

Keywords: Strategic Management, Islamic Education Change, SWOT, Collaborative Strategies

\section{INTRODUCTION}

The new education management model has provided space for schools or stakeholders related to the authority to plan, organize, implement, supervise and control the education system in schools. Also, the acceleration of the development of science, technology and art that penetrates educational institutions makes life in educational institutions even more complicated. 
Educational institutions can no longer accept change but must manage change to make it more beneficial for schools, students and society. Especially Islamic educational institutions.

Islamic education is currently both theoretically and conceptually superior to previous Islamic education and other education. This is based on at least several reasons. First: Al-Quran and Sunnah are the main sources of Islamic teachings that place great importance on education. Second, the condition of Muslims today is richer and more prosperous socially and economically than Muslims in the past. This has a greater impact on improving the quality of Islamic education. Third, from a historical perspective, Muslims have a history and educational progress, namely advances in culture and civilization that were achieved by Muslims during classical times, and have become role models for Europeans.(Abuddin Nata 2017:225)

One of the educational institutions that has an Islamic education curriculum management is Syafana Islamic School (SIS). Syafana Islamic School is a private Islamic education institution located in Serpong Tangerang since 2005, precisely in Gading Serpong, J1. Kelapa Gading Barat AJ 11/10 Gading Serpong, Tangerang. The schools that possess an Islamic education curriculum in the Serpong area are not only SIS, but also Islamic Village, Bina Nusantara School and AlAzhar.

The existence of these Islamic educational institutions creates competition that competes with each other for goodness. With this competition, every school or institution is competing to improve the quality of its educational management. Especially in the strategic management of change in order to achieve quality education services. These Islamic educational institutions have their own advantages. One of the advantages possessed by Syafana Islamic School (SIS) is a curriculum based on collaboration and a combination of the Diknas, Egyptian, and Cambridge curricula.

This competition also triggers the rapid development of Islamic education and demands Islamic schools or educational institutions to determine the proper Islamic education system and management. Such management must achieve the same educational goals in Islamic education. It is intended that Islamic education is following the philosophy of life and views of the nation or state. Because the main purpose of Islamic education is to achieve the goal of human creation, namely to serve Allah SWT in creating a generation who is virtuous and has noble characters.

Previously, Syafana Islamic School had implemented an educational program with a full day system. Every day, starting from the PlayGroup to High School level, there are approximately 2000 (two thousand) students going back and forth from home to school. The fullday program has actually had a big influence on the development of students and students. However, to improve the quality and achieve the main objectives of Islamic education, this year (2021-2022), Syafana Islamic School is making strategic change management innovations to meet the demands of globalization by opening a new program, namely the Boarding School. Of course with a new pattern and management.

The key to the continuation of an educational institution in the midst of change is understanding its position, what is happening, and its preparation to be part of a new world that is changing. Changes in the education system that were previously centralized are now decentralized and implementing a school-based management model (SBM). Likewise, the curriculum and assessment systems that have been implemented, such as competency-based curriculum (CBC) and class-based assessment (PBK), are strengths and opportunities for schools 
to develop strategies, especially in terms of strategic development management change to face new things in this modern world.

In this study, the authors used a SWOT analysis and its application to the strategic management of change in the Islamic educational institution Syafana Islamic School Serpong. The analysis is carried out to identify and measure the strengths, strengths, challenges, weaknesses, opportunities and challenges of the Syafana Islamic School, to make changes in strategic management to improve the quality of Islamic religious education. This of course will be of particular benefit to the institution or its stakeholders.

Seeing that, the authors are interested in conducting research on how strategic management change at Syafana Islamic School is between those previously implementing a full-day program with a change to a boarding school system. With the research title, "Strategic management of change in Islamic educational institutions, a case study in the Islamic educational institution Syafana Islamic Boarding School".

\section{LITERATURE REVIEW Strategic Management}

Strategic management is a phrase consisting of two words "management" and "strategy". Each word has its own meaning. When combined into one, the sentence (terminology) also has its own meaning. Therefore, it is necessary to first discuss the meaning of "management" and "strategy".(Nazaruddin 2020:2-3) Terry, in Nazarudin's, defined management as a process or framework that involves mentors to guide a group of people towards organizational goals or real goals. In this case, management is an activity, and its realization is called managingmanagement. While the implementation is called a manager.(Nazaruddin 2020:3)

Strategic according to Barry, in Nazarudin's is an organizational plan for the future and how to achieve its goals. Tedjo Tripomo, in Nazarudin translating the definition above, "Strategy is about the plan to achieve (or want to be) the future (direction) of the organization and how to achieve the desired state. ${ }^{1}$ Maisah concluded that the definition of strategic management is the steps taken by leaders to achieve organizational goals effectively and efficiently.(Maisah 2020:1) The definition or definition of strategic management in the management science literature has a broad scope and there is no standard definition. This is why the definition of strategic management depends on one's understanding. However, from the various definitions given by management experts, one can find general ideas about strategic management, which is a science that combines management functions to make organizational strategic decisions to achieve organizational goals effectively.

\section{Islamic Education Management}

Before entering into the understanding of Islamic education management, at least the notion of management and Islamic education itself should be understood in the first place. Management is taken from the word to manage, which means to organize or manage. In another sense, management is a process of implementing various activities for the application of a goal and as a skill for people who are managerial to obtain results to achieve goals through the activities and activities of other people.(Feriyanto 2017:4) Furthermore, with the research that

${ }^{1}$ Nazarudin. Manajemen Strategik. ISBN: 978-602-447-292-4. (Cet ke III) 163 hal. (CV. Amanah: Palembang, 2020). Hal. 4 
the author conducted, one of the definitions of management that is exactly appropriate for this research is the definition proposed by Sujana that management is a process of activities carried out in a collective way to produce goals, and management can also be interpreted as an institution in where the activities are conducted.(Sujana 2011:1)

Of the many definitions put forward by experts on the meaning of Islamic education, it can be reduced to two. First: Islamic education is an educational activity carried out with the intent and purpose of realizing Islamic teachings and values. Second: Islamic education is an educational system that is derived from Islamic teachings and values. This means that Islamic education includes many aspects. Among them, teachers, leaders in higher education institutions, principals and other educational personnel are motivated to develop educational activities with the spirit of teaching and Islamic values.(Muhaimin 2011:3-4)

Comprehending the two definitions above, the management of Islamic education can be defined as how to manage and manage Islamic education resources effectively and efficiently in realizing the ideals of development, progress and quality of the process and results of Islamic education itself. In this case, indeed the aspects of Islamic managers and leaders must be embedded in the management of Islamic education.(Muhaimin 2011:5)

\section{Islamic Education Institution Change}

Change is anything that causes the current situation to be different from the situation in the future. The desired change in the context of a group or organizational change is certainly related to an activity to carry out organizational activities by coordinating the expertise of a person or group in realizing certain goals.(Wanuri 2011:89)

Winardi, quoted by Misbah, explained that in other words there was a change from an old condition (status quo) to a new condition (reformist). Change can be automatic or evolutionary, but it can also happen revolutionary. This situation will clearly affect the value of the structure or structure in educational institutions. Therefore, it needs to be targeted by making planned changes and then making improvements in various fields so that the educational institution will become dynamic, reformist, and continue to be up to date.(Winardi 2017:119) Organizational change is the activity of moving an organization from the current situation and condition to future situations and conditions to increase its effectiveness. In an educational institution, the leader or principal of the school is entitled and responsible for the change process. The principal, through his power and authority, has the right to implement changes. Winardi said that the organizational environment is constantly changing, and the organization must carry out various kinds of changes to be able to survive and compete in maintaining the quantity and quality of the institution.(Winardi 2017:2)

Ramayulis, quoted by Rahmat Hidayat, defined that an institution etymologically is the origin of something or a reference, in creating other institutions or organizations that aim to carry out scientific research or carry out certain businesses. As can be understood from the description above, institutions have two meanings, namely: 1) physical, material, and specific meanings, 2) non-physical, non-material, and abstract meanings.(Rahmat Hidayat 2016:164) In terms, Amir Daiem, in Rahmat Hidayat defined an educational institution with a person or institution that is naturally responsible for education. The formulation of the definition was put forward by Amir Daiem who emphasized a responsible attitude to students so that it was a natural need to make it happen, not coercion. 
This means that an educational institution must have a clear and concrete vision. By seeing the current global demands, the vision must be a compass that guides every activity carried out in Islamic educational institutions.(Maisah 2020:58)

\section{RESEARCH METHODS Understanding Swot Analysis}

Industrial and technological advances have penetrated all walks of life of society. Both urban and rural communities. This progress led to a change in behaviour in society. With the development of means of communication and transportation, the world that was once vast has now changed to become smaller. Land and sea are no longer a barrier to reaching other areas. This change has had an impact on the world of education. Therefore, in order to respond to and compensate for these changes, educational institutions must be more open by applying new concepts and of course adjusted to the progress and developments that are being faced.

To respond to these changes, there is a new concept developed in school management or educational institutions, namely SWOT analysis, which is a strategic planning method used to evaluate strengths, weaknesses, opportunities and threats in an educational institution.(Maisah 2020:43) Abdul Hadi also explained the analysis viewed from these four points of view. First: strength in analyzing the advantages or strengths of existing basic resources. Second: weakness (Weakness) in analyzing the limitations of existing resources that can hinder the achievement of educational goals. Third: Opportunity in analyzing the main situations that are favourable for educational organizations or institutions, and fourth: Challenges (Threats) in analyzing the main situations and conditions that are not favourable to the educational situation.(Hadi 2013:145)

In a SWOT analysis, two factors will greatly influence the progress and decline of education. First: dominant factors and second: inhibiting factors. Those that are incorporated into the dominant factor are strengths and opportunities. Meanwhile, the inhibiting factors are weaknesses and challenges. SWOT analysis is an excellent tool for improving quality in educational institutions. By using a SWOT analysis, educational institutions can examine the factors that can affect the performance of educational institutions. Besides, this analysis can logically assist the decision-making process. The decision-making process is related to the vision, mission and goals of an educational institution, and can also be used as a decision-making process to determine strategy.

\section{Types of SWOT Analysis}

Type of SWOT Analysis contains two models: quantitative model and qualitative model.

First Quantitative Model, The basic assumption of the quantitative model is the paired conditions of strengths and weaknesses (Strengths - Weaknesses), opportunities and threats. The reason for this matching condition was assumed because there was always a hidden weakness in every strength, and there was always a threat that had to be watched out for in every open opportunity. This means that the strength $(\mathrm{S})$ of each formula must always have a pair of weaknesses (W), and every chance formula (O) must always have one to one challenge (T).(Salim dkk. 2019:6)

Then, Alif Salim and Agus B Siswanto explained that after formulating and pairing each component, the next step is to carry out an evaluation and assessment process. Evaluation is done by giving a score to each of the sub-components, one of the sub-components compared to other 
sub-components or a vertical line in the same component. The sub-components that determine the course of the organizational process are given a higher score. Evaluation and assessment standards are based on mutual agreement to reduce the subjectivity of evaluations and assessments.(Salim dkk. 2019:6)

Second Qualitative Model, The sequence of the qualitative SWOT analysis is not much different from the sequence of the quantitative model. The biggest difference between the two is in the making of the sub-components for each component. When using a quantitative model, each sub-component has its own advantages. The strengths sub-component is paired with the weaknesses sub-component, and each one the opportunities sub-component. Now, this kind of thing doesn't happen in a qualitative model.(Salim dkk. 2019:7) In this study, the model employed is a qualitative model.

\section{FINDINGS AND DISCUSSION \\ Programs in Syafana Islamic School Serpong}

1. Boarding School Program

Syafana Islamic School was founded in 2005, the programs and levels of education are gradual. Starting from Playgroup and Kindergarten, then Primary, Lower and then Upper Secondary. Among the objectives of the gradual establishment of these levels of education is to ensure that each teaching and learning activity is carried out under the planning and targets to be achieved. After one year running, the entire establishment process from the level of Playgroup to Secondary (SMA) has been carried out very well. Syafana Islamic School has produced high school graduates and continued their education to various universities both at home and abroad. In this year 2021-2022, with the permission of Allah SWT, Syafana Islamic School opens a new program, namely the Boarding School or pesantren. Furthermore, it became Syafana Islamic Boarding School or abbreviated as SIBS. ${ }^{2}$

Among the reasons for the establishment of SIBS was to prepare intensification of programs and activities at Syafana Islamic School coupled with various other varied activities outside formal school hours. If a student is registered as a full day student in the Syafana program, they will undergo the learning process at school from morning to evening. After that they returned to their respective homes and carried out various activities independently. Meanwhile, for boarding students, after accomplishing formal learning activities at school, they immediately complete various activities in the dormitories under the supervision of competent caregivers. (Nanang Firdaus Maduki 2021)

SIBS also provides an alternative choice for students who are interested in getting an education in Syafana but are constrained by distance. For example, students who are out of town or still in Jabodetabek will certainly find it difficult if the learning process is carried out a full day. For that boarding is the right choice. On this basis, at SIBS there will be a separation between the location of the dormitory and the formal classes. The formal class will be held at the current secondary location. Meanwhile, the SIBS dormitory is not far from the secondary location. The distance between the two of them takes approximately 5-10 minutes by using the shuttle bus that has been prepared.(Nanang Firdaus Maduki 2021)

2. Program Designs

\footnotetext{
${ }^{2}$ Nanang Firdaus Masduki, Wawancara tanggal 21 Maret 2021
} 
Talking about pesantren, what is illustrated is people who choose to study in an institution with a boarding system to deepen their knowledge of Islam. Of course, this point of view is not wrong, due to the fact that the previous pesantren institutions were designed like that. However, over time, the current pesantren has opened its doors and is developing not only for those who want to master the knowledge of religion but also for those who want to explore other fields.

In terms of education, Syafana basically adheres to the principle of not differentiating between religious education and general education. Because all basic materials such as religious education, mathematics, and natural sciences are subjects that must be mastered by every student. According to everyone's interests and talents, development is optional. Based on these principles, SIBS is not only suitable for those who wish to major in religion, but also for any student who wants to explore other fields.

Nandang Firdaus explained that generally the program design implemented in SIBS includes 5 (five) elements:

First: Ta'zizul Al Akhlaqiyyah (reinforcement character). There is an Arabic rule that is often used as a reference, namely al akhlak faugqal ilmi or al akhlaq qabla al Ilmi (prioritizing morals before science). Second: Tahfizh Al-Quran 30 juz. All students are obliged to follow the Al-Quran memorization program with an arranged schedule. Third: Leadership and organizational skills. The next SIBS focus is to educate and train the spirit of leadership and to organize students so that they can become future leaders. Leadership and organizational skills are two things that must be trained from an early age, and it must be done repeatedly. So that this skill becomes a habit. Fourth: Curriculum. The educational curriculum implemented by SIBS is a national curriculum and is strengthened by the Al Azhar Egyptian curriculum for Islam and the international curriculum for general knowledge. In addition to the subject curriculum, SIBS will be strengthened through intensive material, namely learning in certain fields handled by experts in their fields. Besides that, it is also supported by various kinds of extracurricular activities. Then, the implementation of the plan is strengthened by strengthening the plan when the activities take place at the Boarding. Fifth: Life skill. The future challenge that will be faced by the younger generation is the extent to which they have qualified life skills, namely various skills or abilities that can adapt and behave positively so that a person can overcome various needs and challenges in life in society. And all of this is a form of independence. At SIBS, students will be provided with various activities, such as muhadharah, broadcasting, entrepreneurship, green farming and others.

\section{Strategic Management of Change in Syafana Islamic Boarding School Serpong}

One of the effective change strategies implemented by Syafana is to combine two programs, namely the full-day program and the boarding school. Through SWOT analysis, the strategy of change can be identified and their level of achievement and success can be measured, namely by using the analysis model of dominant factors (strengths and opportunities) and inhibiting factors (weaknesses and threats).

\section{Factors (Strength dan Opportunity)}

Table 1. Dominant Factors (Strength dan Opportunity)

\begin{tabular}{|l|l|}
\hline \multicolumn{2}{|c|}{ Dominant Factors (Strength dan Opportunity) } \\
\hline 1 & A Clear Purpose, Vision, and Mision \\
\hline & In this case, the main objective of the Islamic education model at Syafana is \\
\hline
\end{tabular}




\begin{tabular}{|l|l|}
\hline & $\begin{array}{l}\text { not only to focus on deepening knowledge of the Islamic religion but also } \\
\text { aims to produce reliable generations in every line of life. So that the alumni } \\
\text { or graduates become skilled and useful human beings in society by sticking } \\
\text { to Islamic principles and values. }\end{array}$ \\
\hline 2 & Participative \\
\hline $\begin{array}{l}\text { This approach is applied not only to the community around Syafana or to } \\
\text { local officials, but also an intensive approach to the parents of students. This } \\
\text { is conducted to establish a strong emotional relationship between leaders, } \\
\text { managers and teachers. If this emotional connection has been well } \\
\text { established, it will make it easier for teachers and managers to understand the } \\
\text { character of their students. }\end{array}$ \\
\hline 3 & $\begin{array}{l}\text { Qualified Teachers } \\
\text { Teachers are experts in their respective fields who have clear qualifications } \\
\text { and are able to work well together. }\end{array}$ \\
\hline 4 & $\begin{array}{l}\text { Favourable educational environment } \\
\text { As it is known that Syafana is located in Serpong. One of the places where } \\
\text { many educational institutions with Islamic nuances gather. This } \\
\text { automatically becomes a supporting factor for the formation of a religious } \\
\text { pattern of life and competing in doing good. }\end{array}$ \\
\hline 5 & $\begin{array}{l}\text { Supporting facilities and infrastructure related to the achievement of goals } \\
\text { Supporting facilities and infrastructure related to the achievement of goals to } \\
\text { concept of change from a full day program to a boarding program, Syafana } \\
\text { has built a new building as a dormitory for students who are interested in } \\
\text { joining the boarding program. }\end{array}$ \\
\hline
\end{tabular}

To measure the success or failure of the change strategy implemented by Syafana, the following indicators can be observed:

Table 2. Indicators of Success

\begin{tabular}{|l|l|}
\hline 1 & $\begin{array}{l}\text { Academically, students who join boarding programs have more control over } \\
\text { school and extracurricular subjects. }\end{array}$ \\
\hline 2 & $\begin{array}{l}\text { In terms of ethics and morals, students who live in dormitories show more of } \\
\text { a polite, polite and obedient attitude towards teachers and managers. }\end{array}$ \\
\hline 3 & $\begin{array}{l}\text { Boarding students have a higher level of piety, that is, they are more obedient } \\
\text { in carrying out religious orders and recommendations. }\end{array}$ \\
\hline 4 & $\begin{array}{l}\text { In society, students who live in dormitories when they come home for } \\
\text { holidays show a more caring attitude and can interact and socialize with the } \\
\text { surrounding community. }\end{array}$ \\
\hline 5 & $\begin{array}{l}\text { Culturally, boarding students are more able to interpret their religious } \\
\text { teachings according to their social environment. }\end{array}$ \\
\hline
\end{tabular}

\section{Factors (Weakness dan Threaths)}

Table3. Inhibiting Factors (Weakness dan Threaths) 


\begin{tabular}{|l|l|}
\hline \multicolumn{1}{|c|}{ Inhibiting Factors (Weakness dan Threaths) } \\
\hline 1 & Unstable Political Systems \\
\hline & $\begin{array}{l}\text { Abdul Hadi argued that the unstable political system in the country and the } \\
\text { life of the nation had brought problems to people's lives. This is an obstacle } \\
\text { to creating a positive educational atmosphere.(Hadi 2013:143) Then, } \\
\text { Mulyasa, followed by Abdul Hadi added, a stable political system is needed } \\
\text { to support resource development through the education system. Therefore, } \\
\text { strong political action from all parties, especially the government, is needed } \\
\text { to improve the education sector, particularly in relation to the education } \\
\text { budget allocation..(Hadi 2013:149) }\end{array}$ \\
\hline 2 & $\begin{array}{l}\text { Inadequate facilities and infrastructure } \\
\text { The lack of educational facilities and infrastructure, such as libraries, } \\
\text { laboratories and learning centres, is a reality in our current education system, } \\
\text { which is also a weakness of education in Indonesia. Also, although the } \\
\text { government has completed the guidebooks, they are still underutilized. }\end{array}$ \\
\hline 3 & $\begin{array}{l}\text { Graduates are less competitive } \\
\text { The low competitiveness of graduates of educational institutions is mainly } \\
\text { caused by the quality of achievement of graduates that is inconsistent with } \\
\text { their goals. As a result, graduates still have difficulty in working. This is also } \\
\text { due to the increasing number of requirements requested by agencies, the } \\
\text { business and the industrial world. Moreover, some of these graduates are not } \\
\text { fluent in foreign languages and are not good at computers and } \\
\text { entrepreneurship. }\end{array}$ \\
\hline 4 & $\begin{array}{l}\text { Low productivity and work management } \\
\text { One of the causes of low work efficiency is the low work ethic and } \\
\text { achievement achieved by students. Good learning achievement as evidenced } \\
\text { by grades and non-academic achievements.(Hadi 2013:150) }\end{array}$ \\
\hline
\end{tabular}

\section{Determination of Strategic Change Management Targets at the Syafana Islamic School}

\section{Islamic Education Institute}

Damri Hasibuan stated that the Director of Syafana Islamic School, Ustadz Nanang Fidaus Masduki, Lc, has great aspirations in building and developing Syafana and eliminating the image that Islamic education institutions are currently out of date, in other languages, less modern. Many people say that Islamic educational institutions do not apply Islamic teachings. For example, in terms of cleanliness, discipline, and not being able to compete with non-Islamic educational institutions in terms of general knowledge. On that basis, the Syafana Islamic School educational institution is established with the aim that this negative image would no longer be a frightening spectre for parents to enrol their children in Islamic educational institutions.

Ustadz Nanang always hopes that Syafana Islamic School graduates will be able to speak many world languages, especially Arabic and English. In addition, Syafana's environment must also be clean, have proper facilities and infrastructure, apply discipline for teachers, managers and students, and have qualified quality so that they can compete in the current era of globalization, but of course still within the corridors and Islamic values. 
Hence, to realize the big goals and ideals of Syafana Islamic School, four strategies are applied:

\section{1) Strategy of Strength Opportunity}

The first pattern in implementing this strategy is by gathering all the strengths that you have and then using all those strengths to take advantage of the multiple opportunities that exist.

Strengths and opportunities at Syafana Islamic School are:

Table 4. STRENGTHS

\begin{tabular}{|c|c|}
\hline \multirow[b]{2}{*}{1} & \\
\hline & $\begin{array}{l}\text { Education Curriculum and National and International } \\
\text { Preparatory Classes }\end{array}$ \\
\hline & $\begin{array}{l}\text { The curriculum used at Syafana Islamic School is a } \\
\text { comprehensive and integrated curriculum. The Diknas Curriculum is } \\
\text { still applied but it is added with an international-based curriculum in } \\
\text { order to achieve high learning standards. Mantazakka (Principal of } \\
\text { High School) said that the international curriculum used is the Al- } \\
\text { Azhar Cairo (Egypt) curriculum for the application of teaching } \\
\text { Arabic and Tahfiz Al-Quran. Meanwhile, for the learning of } \\
\text { English, Science and Mathematics utilizes the Cambridge-English } \\
\text { curriculum. } \\
\text { The combination of the Diknas Curriculum with the Al-Azhar } \\
\text { Egyptian and Cambridge curricula certainly opens up great } \\
\text { opportunities for the development and advancement of Syafana } \\
\text { Islamic School in the international arena. This opportunity is not } \\
\text { wasted by Syafana, right on November 18, 2020 the Islamic } \\
\text { education institution Syafana Islamic School collaborated with } \\
\text { PUSIBA (Center for Islamic Studies and Arabic) and Mumtaza } \\
\text { Center to prepare the advanced education process for high school } \\
\text { students to the tertiary level at Al-Azhar University in Egypt and } \\
\text { universities in Turkey. } \\
\text { In addition, in Syafana, there is also a preparatory class that } \\
\text { provides provision for students to be able to continue their studies at } \\
\text { both national and international institutions. }\end{array}$ \\
\hline 2 & Tahfiz 30 Juz Program \\
\hline & $\begin{array}{l}\text { This program is implemented in stages, starting from the } \\
\text { Kindergarten level by starting to memorize the chapters in } 30 \\
\text { chapters. At the elementary level, the graduates have memorized } 6 \\
\text { chapters. For high school level with a special class to memorize } 30 \\
\text { juz or chapters. } \\
\text { With so many students memorizing the Al-Quran, there is an } \\
\text { opportunity for them to be able to continue to the higher education } \\
\text { level in the Middle East which requires memorizing the Al-Quran at } \\
\text { entry. }\end{array}$ \\
\hline 3 & Having an International Certification \\
\hline & This international certification is in the form of B1, PET, \\
\hline
\end{tabular}




\begin{tabular}{|l|l|}
\hline & $\begin{array}{l}\text { IELTS, and TOEFL. With this capital, the opportunities for students } \\
\text { to be able to enter well-known universities both domestically and } \\
\text { abroad are wide open and very easy. Because students no longer } \\
\text { have to take exams at other institutions to get all these certificates. }\end{array}$ \\
\hline 4 & UK Summer Boarding Courses and Global Youth Summit \\
\hline UK Summer Boarding Courses is an institution with a paid \\
hostel format for international students ranging from 8 to 17 years of \\
age. Meanwhile, the Global Youth Summit is an environmental \\
conference for youth in the Asia-Pacific region. \\
These two programs are part of the flagship program of \\
Syafana Islamic School. This program automatically becomes a \\
great opportunity for students to be able to compete to be part of the \\
two programs. And of course, also an opportunity for Syafana to \\
introduce itself.
\end{tabular}

2) Strategy of Strength Threat

\begin{tabular}{|l|l|}
\multicolumn{2}{|c|}{ Table 5. ANTICIPATION OF THREATS } \\
Communication \\
\hline 1 & \multicolumn{1}{|c|}{ Communication Strategy } \\
\hline & $\begin{array}{l}\text { One of the methods used by the Syafana Islamic School is to } \\
\text { use a communication strategy method that has the aim of continuing } \\
\text { to generate a positive image and to be widely known both at the } \\
\text { national and international levels. This communication strategy does } \\
\text { not only communicate intensively with the community, religious } \\
\text { leaders, community leaders and other institutions in order to achieve } \\
\text { cooperation and collaboration in advancing Islamic education..(Damri } \\
\text { Hasibuan :Interview, Marc 2021) }\end{array}$ \\
\hline
\end{tabular}

3) Strategy of Weakness Opportunity

Table 6. ANTICIPATION OF WEAKNESSES

\section{Weaknesses}

\begin{tabular}{|l|c|}
\hline 1 & Lack of alumni re-generation \\
\hline & $\begin{array}{c}\text { Under these conditions, Syafana would continue to depend on } \\
\text { outside experts and personnel. Meanwhile, staff and experts who are }\end{array}$ \\
\hline
\end{tabular}




\begin{tabular}{|l|l|}
\hline & $\begin{array}{l}\text { not alumni certainly have not been emotionally connected to Syafana. } \\
\text { Therefore, in an effort to anticipate it, because the Director is an } \\
\text { alumnus of the university from the Middle East, one of the effective } \\
\text { ways to build and nurture Syafana, the Foundation accepts graduates } \\
\text { from the Middle East to serve as teaching staff there. (Damri } \\
\text { Hasibuan : Interview, March 2021) }\end{array}$ \\
\hline 2 & $\begin{array}{l}\text { Memorize Al-Quran while studying other subjects } \\
\text { Similar to the weaknesses regarding the method of memorizing } \\
\text { establishing a boarding house or boarding. Weaknesses are used as } \\
\text { opportunities. Opportunities for implementing and succeeding the } \\
\text { boarding school program. }\end{array}$ \\
\hline 3 & $\begin{array}{l}\text { Weak management and administration skills } \\
\text { Finally, there are weaknesses in management and }\end{array}$ \\
administration. To anticipate this weakness, Nanang Firdaus as \\
Director and alumni of Al-Azhar University Egypt, collaborated with \\
OIAA (Al-Azhar Alumni International Organization) in forming the \\
Al-Azhar Alumni Education Institution Management Forum (FPLPA) \\
to assist, especially in the fields of: notary, law and institutions, \\
institutional assistance, institutional management and manhaj \\
wasathiyyah-based curriculum. That way, this weakness is used as an \\
opportunity to collaborate with institutions that have relations to the \\
Middle East. ((Wasatiyah.com, march 2020)
\end{tabular}

4)

\section{Strategy of Weakness Threat}

Table 7. DEFENSIVE

Teacher Quality Assignment and Approach

\begin{tabular}{|l|l|}
\hline 1 & Train and produce teachers with quality \\
\hline & This strategy is carried out by pressing so that every alumnus \\
can become a quality generation. Likewise, for the Al-Quran \\
memorization program, the implementer continues to work hard to \\
find the right format on how to make students memorize the Al-Quran \\
and still be able to communicate and contribute to society. Regarding \\
weaknesses on the management and administration side, the \\
Foundation provides training to the internal managers of the \\
institution, not looking for personnel outside the institution.
\end{tabular}

\section{CONCLUSION AND RECOMMENDATION}

\section{Conclusion}

Previously, the Syafana Islamic School educational institution implemented an integrated curriculum with a system of learning only from morning to evening with formal lessons. Then, Syafana made changes to the curriculum, namely by using a collaborative curriculum and combining the Education, Egypt and Cambridge by implementing the Boarding School learning system to maximize the implementation of the collaborative and merged curriculum. That way, 
opportunities to deepen knowledge of religion, social sciences, ethics, morals and entrepreneurship can be obtained through the boarding school program.

The curriculum is applied by combining and using four strategies. First, the Strength Opportunity Strategy.

The first pattern in implementing this strategy is by gathering all the strengths that you have and then using all those strengths to take advantage of the various opportunities that exist.

Second, the Strong Threat Strategy is based on the strengths that the Syafana Islamic School must have in anticipating existing threats. That is, using all the strengths you have to avoid the various threats that come, both from internal and external.

Third, the Weakness Opportunity Strategy, by overcoming all weaknesses by trying to take advantage of various existing opportunities.

Fourth, Weakness Threat Strategy. Namely based on activities that are defensive and aim to minimize the weaknesses of Syafana Islamic School and at the same time avoid threats.

\section{Suggestions}

Suggestions that can be given regarding the strategic management of changes in Islamic educational institutions at Syafana Islamic School is,

first, for the Syafana Islamic School institution to continue to maximize information system services in order to provide convenience to both parents whose children are studying at Syafana or for parents who are currently looking for the best Islamic education institutions.

Second, improving facilities and infrastructure, managing facilities and infrastructure such as planning, procurement, usage, maintenance, updating, and inventory, so that they are effective in supporting the activities of implementing Islamic education learning in Syafana.

Third, maximize curriculum changes implemented through the Boarding School system, especially in the international curriculum, Egypt and Cambridge.

Fourth, maximizing the teaching staff to be able to continue to explore the potential of foreign languages, Arabic and English.

\section{BIBLIOGRAPHY}

Abuddin Nata. 2017. Pendidikan Isam: Isu Dan Inovasi. Jakarta: FITK Press: UIN Syarif Hidayatulah.

Damri Hasibuan : Wawancara. n.d."Damri Hasibuan."

Feriyanto, Andri. 2017. "Pengantar Manajemen (3 in 1) Untuk Mahasiswa Dan Umum.” P. 182 in. Mediatera: Kebumen.

Hadi, Abdul. 2013. "KONSEP ANALISIS SWOT DALAM PENINGKATAN MUTU LEMBAGA MADRASAH.” Jurnal Ilmiah Didaktika 14(1).

Maisah. 2020. Manajemen Strategik Dalam Perspektif Pendidikan Islam. Salim Media Indonesia: Jambi.

Muhaimin, dkk. 2011. Manajemen Pendidikan Aplikasinya Dalam Penyusunan Rencana Pengembangan Sekolah/Madrasah. Cet ke 3. Kencana Prenada Media Group. 
Nanang Firdaus Maduki. 2021."Wawancara."

Nazaruddin. 2020. Manajemen Strategik. Palembang: CV. Amanah.

Rahmat Hidayat. 2016. Ilmu Pendidika Islam, Menuntun Arah Pendidikan Islam Indonesia. Medan: Lembaga Peduli Pengembangan Pendidikan Indonesia (LPPPI).

Salim dkk. 2019. Analisis Swot Dengan Model Kuesioner. semarang: Semarang.

Sujana. 2011. Dasar-Dasar Manajemen. Bandung: Maju, C V Mandar.

Wanuri. 2011. "Manajemen Perubahan.” Jurnal STIE Semarang 3(1):12.

Wasatiyah. 2020. "Serba Serbi Alumni Azhaar." Retrieved (https://www.wasathiyyah.com/serba-serbi-azhar/kegiatan alumni/28/04/2019/alumni-alazhar-mesir-sepakat-bentuk-fplpa/.).

Winardi. 2017. Manajemen Perubahan (Management of Change. Kencana: Jakarta. 